\title{
The role of work satisfaction as a mediation leadership on employee performance
}

\section{A. Ratna Pudyaningsih ${ }^{a^{*}}$, Joes Dwiharto ${ }^{a}$ and Muhammad Tahajjudi Ghifary ${ }^{a}$}

${ }^{a}$ University of Merdeka Pasuruan, Indonesia

\section{H R O N I C L E}

\section{Article history:}

Received: June 26, 2020

Received in revised format:

June 302020

Accepted: July 26, 2020

Available online:

July 26, 2020

Keywords:

Job Satisfaction

Leadership

Employee Performance

\section{A B S T R A C T}

Leadership is an important factor in providing direction to employees and it can improve employee performance, significantly. When a leader can grow the employees' confidence in carrying out their respective duties, he/she contributes to the performance of the organization. In addition to leadership, job satisfaction is also an important factor which influences on employee performance. To be able to maintain existing resources, companies are required to increase employee satisfaction, increase employee organizational commitment and provide job security for employees. This study aims to analyze the influence of leadership on job satisfaction, analyze the influence of leadership on employee performance, study the effect of job satisfaction on employee performance and analyze job satisfaction as a mediate leadership on employee performance based on path analysis. The result of the analysis shows that leadership influenced job satisfaction and employee performance while job satisfaction affects performance. Finally, the results indicate that job satisfaction mediated the effect of leadership on employee performance.

\section{Introduction}

Basically, every company has a purpose, which requires an improvement of the quality of services. In an effort to improve the quality of service it is necessary to consider various factors such as employee or human resources factors. The employee is the primary source to achieve productivity and creativity of employees are needed in achieving the firms' success (Hettiararchchi \& Jayarathna, 2014; Dappa et al., 2019; Supriyanto et al., 2020). For employees who already exist in a company, leadership plays an essential role for performance improvement. Leadership is an important factor in providing direction to employees, transparency and improve employee performance. Leadership that can improve performance is a leader who can grow the employees' confidence in carrying out their respective duties.

In addition to leadership, job satisfaction is also an important impact on employee performance. To be able to maintain existing resources, companies are required to increase employee satisfaction, increase employee organizational commitment and provide job security for employees (Widiandono, 2003). Every company wishes to achieve its goals and to achieve the desirable objectives. The role of managers is very important to fit the desirable objectives and leaders need to understand the factors that can increase employee satisfaction. Satisfaction is what determines the employees' performance. In order for employee behavior in accordance with company goals, there must be a combination of satisfaction with the desired company.

Job satisfaction is one of the most important factors to get optimal work result. When a person feels satisfied with his/her working conditions, of course, he/she will do everything possible to complete his/her tasks, properly. Job satisfaction can also be formulated as a general response of employees in the form of behavior displayed by employees as a result of perceptions about matters associated with work. An employee who enters and joins the organization has a set of desires and past 
experiences that unite and form a hope that can be fulfilled in the workplace. One thing that can affect performance is employee satisfaction (Sinungan, 2008: 48), which have an impact for the improvement of employee performance.

At the Department of Cooperatives, Industry and Trade Pasuruan, employee satisfaction is necessary to achieve organizational goals. Thus it is clear that the role of leadership is very important, so that employees are satisfied in working at the Department of Cooperatives, Industry and Trade Pasuruan Regency can perform their tasks in accordance with the standards or objectives of the organization that has been determined. Good performance is expected in the Department of Cooperatives, Industry and Trade Pasuruan Regency since the work they do is very closely related to the progress of the government of Pasuruan, especially in the field of Cooperatives, Industry and Commerce.

Based on the background, the objectives of this research are: to analyze the influence of leadership on job satisfaction, to analyze the influence of leadership on employee performance, to analyze the effect of job satisfaction on employee performance and to analyze job satisfaction to mediate leadership on employee performance.

\section{Literature review}

\subsection{Leadership}

Amirullah (2004: 245) defines leadership as a person (leader) that influences others to cooperate in carrying out interrelated tasks in order to achieve the desired goals of the leader and/or group. The definition emphasizes the problem of the relationship between the person influencing (leader) and the affected person (subordinate). According to Mulyasa (2005: 107) leadership is defined as activities to influence people who are directed towards the achievement of organizational goals. While the leadership according to Hasibuan (2008: 167) is defined as "the way a leader affects the behavior of subordinates, to work together and productively to achieve organizational goals".

\subsection{Job satisfaction}

There are different definitions for job satisfaction. According to Ibrahim (2007: 154), job satisfaction is associate with the attitude of employee. A person will be satisfied with the work if the level of his needs is met, while the needs include physiological needs, safety needs, social needs, reward, and prestige needs statement or self-fulfillment. Self-employed behavior is essential for all the actions a person undertakes or the way of acting that shows a person's behavior and the action which can be measured or observed. The members of an organization can be categorized into two types, namely people with positive or negative behavior (Siagian, 2009: 138; Boudabbous, 2020).

According to Hasibuan (2008: 202), job satisfaction as a pleasant emotional attitude towards the work conditions. This attitude is reflected by work morale, discipline, and work performance. Meanwhile, according to Mangkunegara (2009: 117) job satisfaction can be described as a feeling of supporting or not supporting self-employed associated with the work condition. Furthermore, according to Luthan (2006: 243), job satisfaction is the result of employee perceptions of how well the work provides what is considered important. In general, in the field of organizational behavior, job satisfaction is the most important and often learned attitude. Meanwhile, according to Martoyo (2006: 142), job satisfaction is meant the emotional state of employees between the value of repayment of employee services of the company/organization with the level of value of the services desired by the employees concerned. This employee benefits, in the form of financial or nonfinancial. When satisfaction occurs, it is generally reflected in the employee's feelings toward his/her work, which is often manifested in the employee's positive attitude toward his job and everything he or she is facing or assigned to in his/her workplace.

\subsection{Performance}

According Hasibuan (2007: 94) performance is a work achieved by employees in carrying out tasks assigned based on the employees' skills, experience, and sincerity and time. Performance is a combination of 3 (three) important factors, namely the ability and acceptance of the explanation of task delegation, as well as the role and level of motivation of an employee. The higher the numbers for these three factors, the greater the performance of the employees concerned. Meanwhile, according to Hariandja (2002: 195) "the performance is the work produced by employees or real behavior that is displayed". Another opinion expressed by Mangkunegara (2005: 67) that performance is "the quality work achieved by an employee in performing their duties in accordance with the responsibilities given to him".

\subsection{Hypothesis}

$\mathrm{H}_{1} \quad$ : Leadership affects job satisfaction.

$\mathrm{H}_{2}$ : Leadership affects employee performance.

$\mathrm{H}_{3}$ : Job satisfaction affects employee performance.

$\mathrm{H}_{4}$ : Job satisfaction mediates leadership toward employee performance. 


\section{Methodology}

\subsection{Research design}

Based on the purpose of this research, the research design is the design of causal research. According to Sanusi (2014: 14), the design of causality is a research design that is structured to examine the possibility of causality between variables. In this design, generally the causal relationship is predictable by the researcher, so the researcher can declare the classification of exogenous variables, intervening variables, and endogenous variables.

\subsection{Population, Samples and Sampling Techniques}

The population in this study includes all 48 employees of the Department of Cooperatives, Industry and Trade Pasuruan. The foundation or basis of sampling is the opinion of Arikunto (2009: 134) which states if the subject is less than 100 then it is a good idea to consider all the population for the study. However, if the number of subjects is large, it can be taken between $10 \%-15 \%$ or $20 \%-25 \%$ or more. Based on this opinion, the number of samples in the study amounted to 48 employees, so that the sampling of the research conducted by using the census method which means taking all employees as respondents.

\subsection{Operational Definition of Variables}

\section{a. Leadership}

One's way of influencing others to achieve goals. The indicators used in this research are: fair, giving suggestions, supporting the achievement of goals, as a catalyst, creating a sense of security, as a representative of the organization, a source of inspiration and respect.

\section{b. Job satisfaction}

Job satisfaction is the attitude that workers have about employees' work. Indicators used are as follows: employment, salary, supervisory or supervisory work, promotion opportunities, and co-workers.

\section{c. Employee performance}

Performance is a result of a job as a contribution to a company based on quantity, quality, and timeliness, as measured by quantity of work, quality of work and timeliness.

\subsection{Data analysis method}

Analysis technique in this research uses path analysis. Path analysis is a technique for analyzing the causal relationships that occurs in multiple regression if the independent variables affect the dependent variable not only directly but also indirectly (Sarwono, 2006). Path analysis is a direct development of multiple regression with the aim of providing an estimate of the magnitude and significance of hypothetical causal relationships within a variable set of variables (Sarwono, 2006). For the data analysis in this research, we use SPSS (Statistical Program for Social Science) 19 For Windows.

\section{Analysis and interpretation}

\subsection{Analysis}

\section{The effect of leadership on job satisfaction}

The prediction of path coefficient shows the influence of competence and leadership on job satisfaction which is accomplished by using regression analysis. Path coefficient is obtained from standardized regression coefficient (beta). More details description of regression analysis results obtained are presented in Table 1.

\section{Table 1}

Coefficient Test Result of Path from Leadership to Job Satisfaction

\begin{tabular}{lccccc}
\hline Model & \multicolumn{2}{c}{ Unstandardized coefficients } & Standardized Coefficients & & S \\
\cline { 2 - 5 } & $\mathrm{B}$ & Std. Error & & \\
\hline Constant & 0.974 & 0.428 & 0.027 & \\
Leadership & 0.760 & 0.096 & 0.758 & 7.277 \\
\hline
\end{tabular}

Based on the results of Table 1 leadership has a significant and positive effect on job satisfaction $(\mathrm{B}=0.758, \mathrm{Sig} .=0.000)$ when the level of significance is one present.

\section{Leadership Path Coefficient and Job Satisfaction on Performance}

The prediction of path coefficient shows the influence of leadership and job satisfaction on performance is accomplished by using multiple regression analysis. Path coefficient is obtained from standardized regression coefficient (beta). For more details description of regression analysis results obtained are presented in Table 2 as follows. 
Table 2

Results of Path Coefficient Test of Leadership and Job Satisfaction on Performance

\begin{tabular}{lcccc}
\hline Model & \multicolumn{2}{c}{ Unstandardized coefficients } & Standardized Coefficients & \\
\cline { 2 - 5 } & $\mathrm{B}$ & Std. Error & & $\mathrm{t}$ \\
\hline Constant & 0.970 & 0.358 & & \\
Leadership & 0.433 & 0.117 & 0.490 & 2.205 \\
Job Satisfaction & 0.333 & 0.117 & 0.377 & 3.689 \\
\hline
\end{tabular}

Dependent Variable: Performance

According to the results of Table 2, leadership has a significant effect on performance $(B=0.490)$, when the level of significance is one percent. Job satisfaction also has a significant effect on performance $(\mathrm{B}=0.377)$, when the level of significance is one percent. Based on the three paths, the overall path analysis results can be presented in Fig. 1.

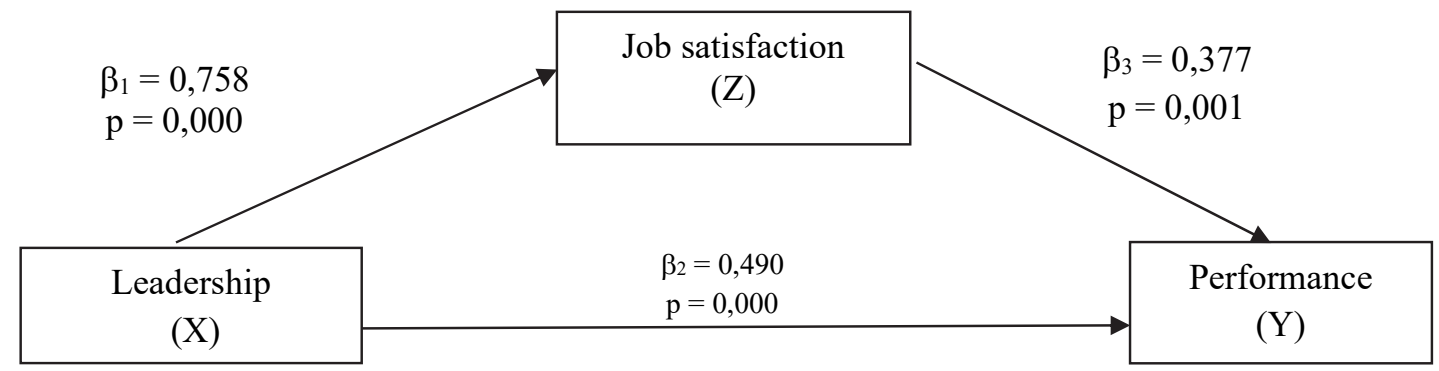

Fig. 1. Path Analysis Results

c. Direct Influence, The Indirect Influence of Leadership on Performance through Job Satisfaction

Based on the result of sub structure analysis 1 , and sub-structure 2 can be arranged indirect influence, the analysis result is presented in Table 3.

Table 3

Direct Effect, Indirect Effect, and Total Effect

\begin{tabular}{lcc}
\multicolumn{1}{c}{ Variables } & Direct Effect & Indirect Effect \\
\hline Leadership $\rightarrow$ Job satisfaction & 0.758 & - \\
Job satisfaction $\rightarrow$ Performance & 0.377 & - \\
Leadership $\rightarrow$ Job satisfaction $\rightarrow$ Performance & 0.490 & 0.758 \\
\hline Souffect & 0.377 \\
\hline
\end{tabular}

Source: Primary data processed.

Based on Table 3, it appears that the indirect and direct effects of total leadership on performance (0.776) is greater than direct influence (0.490). These results indicate that job satisfaction plays as an intervening variable on the effect of leadership on performance because the total value is greater than the direct effect.

\subsection{Interpretation}

Leadership affects job satisfaction, which means that the better the behavior of the Leadership Agency by directing and supporting employees, the better the results of work accomplished to achieve organizational goals, and even achieve increased job satisfaction. Leadership indicators that can increase job satisfaction give suggestions reflected from the Leader to give morale advises to employees. Effective leadership has a varied style with followers' readiness. Such readiness refers to the ability of employees or work teams as well as the ability to achieve certain tasks. Ability refers to the self-motivation and commitment of followers to carry out the given task. Leadership is an effort to influence many people through the process of communication to achieve organizational goals and the actions are expected to generate positive changes to coordinate the organization. The results of this study are in line with Baltaci et al. (2012) and Riana et al (2015) which proves that leadership affects job satisfaction.

Leadership has a significant effect on employee performance. Leadership is the power to influence a person, whether in doing something or not doing something. A leadership indicator that is capable of improving performance is giving suggestions reflected by the Leader giving morale to the employee. Leaders must be able to combine the needs of their subordinates with the needs of the organization and the needs of society as a whole, through the task of leadership that encourages subordinates to have the competence and opportunities to develop in anticipating every challenge and opportunities in the work so that the ability of leaders in moving and empowering employees could affect the performance of employees. Leadership is an individual behavior that in each activity will give effects such as influence, motivation, and decision-making patterns by followers or subordinates. Subordinates will volunteer to do work in order to achieve the goals to be achieved. The authoritative leader will create the feeling of his subordinate's salute as well as his partner to do something favorable to the 
leader. Likewise, authority followed by good exemplary by the leader will create a harmonious atmosphere. The effort and success of instance in measuring, directing in utilizing the employee also influenced by the role of leadership. A leader must have the ability to influence subordinates in the implementation of their work to achieve organizational goals effectively and efficiently. The results of this study are similar to Suprapta et al. (2015) and Chandra and Priyono (2016) stating that leadership affects employee performance.

Leadership has a significant effect on employee performance. Leadership is the power to influence a person, whether in doing something or not doing something. A leadership indicator that is capable of improving performance gives suggestions reflected by the Leader giving morale to the employee. Leaders must be able to combine the needs of their subordinates with the needs of the organization and the needs of society as a whole, through the task of leadership that encourages subordinates to have the competence and opportunities to develop in anticipating every challenge and opportunities in the work so that the ability of leaders in moving and empowering employees will affect the performance of employees. Leadership is an individual behavior that in each activity will give effects such as influence, motivation, and decision-making patterns by followers or subordinates. Subordinates will volunteer to do work in order to achieve the goals to be achieved. The authoritative leader will create the feeling of his subordinate's salute as well as his partner to do something favorable to the leader. Likewise, authority followed by good exemplary by the leader will create a harmonious atmosphere. The effort and success of instance in measuring, directing in utilizing the employee also much influenced by the role of leadership. A leader must have the ability to influence subordinates in the implementation of their work to achieve organizational goals effectively and efficiently. The results of this study are similar to Riana et al. (2015) and Chandra and Priyono (2016) stating that leadership affects employee performance.

Job satisfaction can mediate the influence of leadership on the performance of employees, which means that leadership can improve employee performance if employees feel satisfied working in the Office of Cooperatives, Industry and Trade Pasuruan. Employee appraisal of the job with his condition is closely related to employee job satisfaction. This is caused by a positive assessment which can increase employee job satisfaction, while a negative assessment can lead to employee job dissatisfaction. The ability of leaders to create a conducive organizational climate can also lead to employee job satisfaction. Therefore, the leadership must be able in accordance with the situation and needs of employees. Leaders recognize the existence of employees can be seen as giving the opportunity to employees to rise positions and classes. This recognition can also be seen when the leader rebukes and smiles to the employee so that the employee feels appreciated. The relationship between the leadership and employees will be harmonious if the leader is able to adjust the leadership style to the situation faced. The existence of appropriate leadership is expected to provide job satisfaction to employees. Job satisfaction is a pleasant and unpleasant feeling associated with the work of the employee and his or her condition.

\section{Conclusion and recommendations}

\subsection{Conclusion}

Leadership influence on job satisfaction, which shows that the better the leadership applied in the Office of Cooperatives, Industry and Trade Pasuruan, the higher the job satisfaction of employees of the Department of Cooperatives, Industry and Trade Pasuruan. Leadership significantly affects the performance, which means that the better leadership applied to the Office of Cooperatives, Industry, and Trade Pasuruan regency can improve employee performance. Job satisfaction affects the performance, which means that the higher the employee job satisfaction, the higher the level of performance of employees of the Department of Cooperatives, Industry and Trade Pasuruan. Job satisfaction mediates the influence of leadership on performance. The higher the leadership then the performance will increase if employees feel satisfied working with the Department of Cooperatives, Industry and Trade Pasuruan.

\subsection{Recommendations}

Leaders should give rewards to employees who have good work so that employees feel satisfied and have an impact on performance improvement. For further research should be developed job satisfaction as a performance booster.

\section{References}

Amirullah. (2004). Pengantar Manajemen. Yogyakarta: Graha Ilmu.

Arikunto, S. (2009). Prosedur Penelitian Suatu Pendekatan Praktis. Jakarta: Bina Aksara.

Baltaci, F., Kara, E., Tascan, E., \& Avsalli, H. (2012). The effects of leadership on job satisfaction (visionary leadership, transformational leadership, transactional leadership). International Journal Symposium on Sustainable Development, $1(31), 220-226)$.

Boudabbous, S. (2020). The relationship between job satisfaction and performance at work: case of Tunisian accounting firms. Accounting, 6(3), 231-240.

Chandra, T., \& Priyono. (2016). The influence of leadership styles, work environment and job satisfaction of employee performance - Studies in the School of SMPN 10 Surabaya. International Education Studies, 9(1), 131-140. 
Dappa, K., Bhatti, F., \& Aljarah, A. (2019). A study on the effect of transformational leadership on job satisfaction: The role of gender, perceived organizational politics and perceived organizational commitment. Management Science Letters, 9(6), 823-834.

Hariandja, M. T.E. (2002). Manajemen Sumber Daya Manusia: Pengadaan, Pengembangan, Pengkompensasian, dan Peningkatan Produktivitas Pegawai. Jakarta: Gramedia Widiasarana Indonesia.

Hasibuan, M. S. P. (2008). Organisasi dan Motivasi: Dasar Peningkatan Produktivitas. Jakarta: Bumi Aksara. . (2007). Manajemen Sumber Daya Manusia. Jakarta : Bumi Aksara.

Hettiararchchi, H.A.H., \& Jayarathna, S.M.D.Y. (2014). The effect of employee work related attitudes on employee job performance: A study of tertiary and vocational education sector in Sri Lanka. IOSR Journal of Business and Management (IOSR-JBM), 16(4), 74-83.

Ibrahim. (2007). Penelitian dan Penilaian Pendidikan. Bandung : Sinar Baru Algensindo.

Luthan, F. (2006). Organizational Behavior. $7^{\text {th }}$ ed., McGraw-Hill Inc.

Mangkunegara, A.A A. P. (2009). Manajemen sumber Daya Manusia Perusahaan. Bandung: Remaja Rosda Karya . (2005). Evaluasi Kinerja Sumber Daya Manusia. Cetakan Pertama. Bandung : PT. Refika Aditama.

Martoyo, S. (2006). Manajemen Sumber Daya Manusia. Yogyakarta: BPFE. . 2000. Manajemen Sumber Daya Manusia. Yogyakarta : BPFE.

Mulyasa, E. (2005). Menjadi Guru Profesional. Bandung: PT. Remaja Rosda Karya.

Sanusi, A. (2014). Metodologi Penelitian Bisnis. Cetakan Kelima. Penerbit Salemba Empat. Jakarta.

Sarwono, J. (2006). Metode Penelitian Kuantitatif dan Kualitatif. Yogyakarta: Graha Ilmu.

Siagian, S. P. (2009). Manajemen Sumber Daya Manusia. Jakarta: Bumi Aksara.

Sinungan, M. (2008). Produktivitas Apa dan Bagaimana. Jakarta: PT. Bumi Aksara.

Supriyanto, A., Ekowati, V., \& Maghfuroh, U. (2020). Do organizational citizenship behavior and work satisfaction mediate the relationship between spiritual leadership and employee performance?. Management Science Letters, 10(5), 1107-1114.

Riana, I. G., Sintaasih, D. K., \& Suprapta, M. (2015). Pengaruh kepemimpinan terhadap kepuasan kerja dan kinerja karyawan (studi pada Wake Bali Art Market Kuta-Bali). E-Jurnal Ekonomi dan Bisnis Universitas Udayana, 4(6), $430-442$.

Widiandono, H. (2003). Dampak Locus Of Control terhadap Pengaruh insentif non finansial pada kepuasan kerja karyawan UKM. Tesis. Program Magister Sains. FE. UGM.

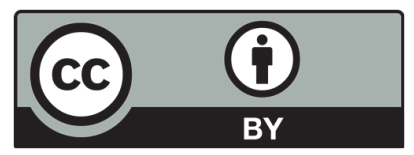

(C) 2020 by the authors; licensee Growing Science, Canada. This is an open access article distributed under the terms and conditions of the Creative Commons Attribution (CC-BY) license (http://creativecommons.org/licenses/by/4.0/). 